\title{
ANALISIS ANGGARAN RITUAL ADAT SAPU BERBASIS MOBILE WEB
}

\author{
Emanuel Safirman Bata \\ Program Studi Teknik Informatika, STIKOM Uyelindo Kupang \\ Jln. Perintis Kemerdekaan I - Kayu Putih - Kupang - NTT - Indonesia \\ E-mail:manuel_bata@yahoo.co.id
}

\begin{abstract}
The Sapu ceremony is a ceremony carried out by the people of So'a in general and the people of Lo'a in particular. This ceremony is held only for adult men both those who are married and those who have not. To be able to carry out a successful event requires careful planning and good implementation. The choice of place of ceremony, invitation, consumption and luggage must be planned from the start. Some of the reasons for the swelling rituals of traditional Sapu rituals are that the organizers of the rituals focus less on the amount of the budget, follow all the wishes of others, lack information, handle everything themselves and are less strict in determining the number of guests. Traditional Sapu rituals, like other projects, require careful planning in which the amount of the budget is followed by the deadline that must be met. Planning traditional Sapu rituals is a complex $j o b$, and can be large and spend a considerable amount of time. If it is not well planned, the traditional Sapu ritual cannot run smoothly. Based on these problems, a mobile-based website was built that can help the admin, calculating the amount of budget needed to hold the traditional Sapu ritual. Facilitate the process of recapitulation and printing of financial reports per participant and total funds overall. In terms of appearance, it is good, interactive and user friendly, easy to read and understand, and the choice of colors that are comfortable and beautiful to look at. The website is created using the PHP programming language. To manage the database management system (DBMS), MySQL is used.
\end{abstract}

Keywords: Budget, Rituals, Sapu, Mobile Web

\section{PENDAHULUAN}

Seiring perkembangan ilmu pengetahuan dan kemajuan teknologi yang mempengaruhi tata kehidupan masyarakat, nilai-nilai kebudayaan masyarakat setempat akan tergeser dari posisinya yang menyebabkan dan mempengaruhi struktur kebudayaan maupun ekonomi apabila masyarakat itu sendiri tidak peka dalam mengikuti perkembangan zaman serta terbuai dalam arus globalisasi.

Adat atau kebudayaan yang berlaku pada suatu masyarakat merupakan perwujudan dari tata nilai sosial yang dimiliki oleh kelompok masyarakat sebagai bagian dari kehidupan masyarakat itu. Tradisi dan adat biasanya dilakukan melalui sistem yang sudah ditetapkan oleh pewaris kepada penerima warisan budaya dalam suatu daerah seperti halnya yang tercipta pada masyarakat Desa Lo'a melalui "ritual adat sapu" yang mana ritual ini dilakukan dalam rangka mengangkat derajat seorang pria dalam tatanan kehidupan budaya atau dalam hukum adat daerah setempat. Memperbincangkan unsur kebudayaan asli berarti tercakup pula unsur kebudayaan sapu pada masyarakat Desa Lo'a, Kecamatan So'a, Kabupaten Ngada. Upacara ini biasanya diadakan setiap lima tahun sekali dan masih berlangsung sampai saat ini.

Upacara sapu merupakan upacara yang dilakukan oleh masyarakat So'a umumnya dan masyarakat Lo'a pada khususnya. Upacara ini dilaksanakan hanya bagi kaum lelaki dewasa baik yang sudah berkeluarga maupun yang belum. Pelaksanaan upacara ini dilakukan bagi orang yang telah mampu dan bersedia dalam hal ketersediaan dana. Untuk dapat melaksanakan acara yang sukses membutuhkan perencanaan yang matang dan pelaksanaan yang baik. Pemilihan tempat upacara, undangan, konsumsi dan barang bawaan (babi, beras, gula dan kopi) harus sudah direncanakan dari awal. Beberapa hal penyebab anggaran ritual adat sapu membengkak adalah pihak penyelenggara ritual kurang fokus pada jumlah anggaran, 
mengikuti semua keinginan orang lain, kurang mencari informasi, menangani semua hal sendiri dan kurang tegas dalam menetapkan jumlah tamu. Ritual adat sapu, sama seperti proyek lainnya, membutuhkan perencanaan yang cermat yang mana jumlah anggaran diikuti dengan tenggang waktu yang harus dipenuhi. Perencanaan ritual adat sapu adalah pekerjaan yang kompleks, dan dapat menjadi besar serta menghabiskan waktu yang tidak sedikit. Jika tidak direncanakan dengan baik maka ritual adat sapu tidak dapat berjalan dengan lancar.

Berdasarkan permasalahan di atas maka dengan bantuan teknologi, penulis akan membangun sebuah website yang dapat membantu merencanakan anggaran ritual adat sapu. Websiteini akan membantu merekomendasikan tempat upacara, konsumsi, barang bawaan (babi, beras, gula dan kopi), photographer, dan jumlah undangan berdasarkan budget yang dimiliki. Dengan demikian pihak penyelenggara pesta dapat menghemat waktu, uang dan ketenangan pikiran dalam mempersiapkan ritual adat sapu.

\section{METODE PENELITIAN}

Berikut ini akan dibahas lima penelitian yang mirip dengan topik penelitian penulis. Penelitian-penelitian tersebut dijadikan sebagai acuan atau masukan bagi penulis dalam pengembangan sistem.

Perangkat lunak perencanaan anggaran pesta pernikahan (eWedding). Perangkat lunak tersebut mampu merekomendasikan tempat resepsi, photographer, catering, salon dan souvenir berdasarkan lokasi pesta, rencana jumlah tamu yang akan diundang dan budget yang dimiliki. eWedding dibuat dengan menggunakan bahasa pemrograman Visual Basic 6.0. Sedangkan untuk mengelolah Database Management Sistem (DBMS) digunakakan Microsoft Accses 2007. Berdasarkan hasil uji responden disimpulkan bahwa secara umum sistem ini sudah memenuhi tujuan utamanya yaitu dapat memberikan kontribusi yang baik terutama dalam hal perencanaan anggaran pesta pernikahan [1]

Erlin dalam penelitiannya yang berjudul: Ritual Adat Sapu di Desa Lo'a kecamatan So'a Kabupaten Ngada, menjelaskan bahwa ritual adat sapu dalam tradisi masyarakat desa Lo'a merupakan warisan leluhur yang patut dilestarikan, dikembangkan dan dibanggakan.
Tradisi tersebut diwariskan oleh leluhur serta diyakini oleh masyarakat adat desa Lo'a. Ritual adat sapu hanya untuk dilaksanakan bagi kaum lelaki dewasa. Inti dari ritual adat sapu tersebut adalah sebagai upacara inisiasi atau pendewasaan seorang lelaki sehingga memperoleh legitimasi atas status sosialnya oleh masyarakat adat setempat. Dalam ritual adat sapu terkandung beberapa nilai seperti nilai religius dan nilai sosial serta memiliki fungsi yang sangat berpengaruh dalam kehidupan bermasyarakat adat desa Lo'a sehari-hari seperti fungsi religus, fungsi solidaritas dan fungsi sosial [3].

Terkait dengan perencanaan anggaran, Djauhari dalam skripsinya yang berjudul: Analisis Anggaran Biaya Operasional pada PT. Pelabuhan Indonesia I Medan menjelaskan bahwa untuk menghindari terjadinya pembengkakan biaya, perlu dilakukan analisis anggaran terlebih dahulu. Anggaran biaya operasional memiliki peanan dalam menunjang efektivitas pengendalian biaya operasional pada PT. Pelabuhan Indonesia I Medan, hal tersbut dapat dilihat dari: anggaran biaya operasional digunakan sebagai alat pedoman kerja. Hal tersebut sangat membantu mengarahkan dan menghalangkan keraguan pelaksana dalam menjalankan kegiatan operasional [2]

Masi dalam topik yang sama, Megawati dalam skripsinya yang berjudul: Proses Penyusunan Realisasi Anggaran Penerimaan dan Pengeluaran Kas pada Rumah Sakit umum Daerah Salah Tiga, memaparkan bahwa perencanaan anggaran terkait proses penerimaan dan pengeluaran merupakan poin yang sangat penting dan perlu dilakukan sebelum direalisasikan. Hal ini akan sangat membantu untuk menghindari terjadinya pembengkakan atau kekurangan anggaran [4].

Sementara itu, Nurtanto dan Adnanmahasiswa STMIK AMIKOM Yogyakarta membangun aplikasi pendataan kependudukan, pendapatan dan pengeluaran desa di Desa Kalidengen. Dalam penelitian tersebut Nurtanto dan Adnan menggunakan sistem baru berbasis komputer sehingga dapat mempermudah petugas balai desa dalam penyimpanan dan pemrosesan data sehingga menghemat tempat penyimpanan berkas, efektif dan efisien. Membantu petugas keuangan dalam mengorganisir pendapatan dan pengeluaran desa [5].

Berdasarkan kelima penelitian di atas maka penulis menyimpulkan bahwa masalah terkait perencanaan anggaran ritual ada sapu 
dapat diselesaikan dengan membangun sebuah website, dengan demikian dapat membantu masyarakat atau pihak penyelenggara untuk menyelenggarakan ritual ada sapu.

\section{PROSEDUR PENELITIAN}

1. Tujuan ritual adat sapu

Tujuan merupakan sasaran atau target yang ingin dicapai dalam penyelengaraan kegiatan. Tujuan juga merupakan arah pandang yang dibidik dalam menyelenggarakan sebuah kegiatan yang dapat memberikan manfaat serta kegunaan sebagai dampak dari kegiatan tersebut [3].

Adapun tujuan utama yang ingin dicapai dalam pelaksanaan ritual adat Sapu yaitu untuk membentuk kepribadian dan meningkatkan status sosial seorang lelaki dewasa dalam kaitan dengan hukum adat setempat dan tampil berwibawa serta kepadanya akan diletakkan beban tanggung jawab yang lebih besar terhadap dirinya, keluarga maupun kepada masyarakat dan dalam segala persoalan adat ia dapat mengambil bagian secara aktif dan menyeluruh[3].

Menurut keyakinan warga desa Lo'a, dengan adanya pelaksanaan ritual adat Sapu, seseorang dapat memulai segala sesuatu dalam kehidupan bermasyarakat secara lebih teratur lagi. Hal ini dapat dilihat dari beberapa hal di antaranya pelaku Sapu dituntut untuk bersikap lebih bijaksana lagi dalam mengatur rumah tangga, serasi dan seimbang dalam memenuhi segala kewajiban dan haknya dalam kehidupan keseharian dan berusaha agar pelaku Sapu dapat terlibat langsung menangani ritual adat yang lainnya. Kaadaan ini kemudian menghantarnya pada suatu posisi yang lebih tinggi dalam status sosial terutama menurut perspektif adat desa Lo'a [3].

2. Proses ritual adat sapu

Ritual adat Sapu dalam tradisi masyarakat desa Lo'a merupakan warisan leluhur yang patut dilestarikan, dikembangkan dan dibanggakan. Tradisi ini diwariskan oleh leluhur serta diyakini oleh masyarakat adat desa Lo'a. Ritual adat Sapu hanya untuk dilaksanakan bagi kaum lelaki dewasa. Inti dari ritual adat Sapu ini adalah sebagai upacara inisiasi atau pendewasaan seorang lelaki sehingga memperoleh legitimasi atas status sosialnya oleh masyarakat adat setempat [3].

\section{a. Persiapan}

Persiapan merupakan salah satu faktor utama untuk membicarakan hal-hal yang berhubungan dengan upacara
Sapu. Pada tahap persiapan ini keluarga yang akan menyelenggarakan upacara Sapu mengundang keluarga terdekat untuk duduk bermusyawarah menyangkut penyelengaraan upacara Sapu. Keluarga dekat yang hadir dalam tahap persiapan ini adalah keluarga dekat dari pihak bapak dan mama. Penyelenggaraan musyawarah sehubungan dengan perlaksanaan upacara Sapu dilaksanakan pada rumah atau orang yang akan menyelenggarakan upacara Sapu. Sedangkan yang memimpin musyawarah dalam tradisi adat desa Loa adalah Mori ema. Mori artinya tuan, ema artinya bapak. Mori ema artinya orang yang dituakan dalam keluarga. Orang ini sudah berpengalaman dalam tradisi adat Loa juga yang bersangkutan sudah mejalankan ritual adat Sapu.

Tahapan persiapan ini dilaksanakan seminggu sebelum dilaksanakan upacara Sapu. Pada acara persiapan Mori ema bersama Mori sapu serta orang tua kandung memaberikan sejajian untuk leluhur di Sui Hazo. Sui Hazo adalah tempat untuk diletakan sesajian yang bentuknya segi empat terletak di sudut kiri kamar keluarga. Pemberian sesajian ini dipimpi oleh mori ema, dengan permohonan sebagai berikut: Mea ebu nusi, mai kita ka sama-sama noo emu ana miu dia nenga dhoro tau ka. Mai miu page pengapenga noo ana miu dia hona wi mea ngo ngani wi molo. Artinya wahai leluhur yang berada di singgasana turun bersama kami makan dan minum hasil karya kami. Berikan kami hasil berlimpah dan kesehatan jasmani serta tuntunlah kami agar pelaksanaan upacara Sapu anak-cucu kalian berjalan dengan baik.

Adapun hal-hal yang dibicarakan pada masa persiapan upacara Sapu menyangkut dengan sarana dan prasarana upacara seperti babi, beras, sirih pinang, kayu, uang, dan lain sebagainya juga dibicarakan berapa keluarga yang diundang untuk mengikut upacara adat Sapu. Kepala keluarga yang diundang tersebut adalah para sahabat dan handaitaulan baik dari keturunan lurus pihak suami, maupun pihak istri serta pihak 
keluarga bapak dan mama yang hidup dan menetap di luar wilayah kampung Lo'a [3].

Selain persiapan dari materi dari Mori Sapu pada kesempatan yang sama juga semua anggota keluarga yang hadir dengan suka rela akan memberikan sumbangan beberapa materi yang dirasa masih kurang. Hal ini dilakukan karena pada pelaksanaan upacara semua Mori Sapu dan keluarganya harus memberikan makan-minum kepada seluruh warga yang hadir. Dalam bahasa adat desa Loa dikenal dengan sebutan Ho'o Bo'a dan Ulu Eko artinya memberi makan kepada sanak-saudara, sahabat, dan kerabat. Jadi bukan hanya keluarga dekat tetapi warga yang hadir pada upacara Sapu harus diberi makan [3].

b. Upacara inti

Pelaksanaan ritual adat Sapu hanya membutuhkan waktu satu hari saja. Acara inti dimulai dari subuh pukul empat. Pada saat itu semua pelaku Sapu diharuskan untuk pergi membersihkan diri di kali. Membersihkan diri di kali melambangkan pemurnian dan kesucian yaitu bahwa para pelaku Sapu sudah boleh mengambil bagian dalam upacara-upacara adat dan pada saat itulah kesetaraan kedudukan mereka sudah diakui oleh warga suku [3].

Setelah mandi, mereka mengenakan pakaian adat dengan baju bewarna putih, Boku toro (penutup kepala/ lesung), Loge tua (di letakan di atas boku), Bere gari dan nai ragi (kain adat). Dengan mengenakan pakayan adat maka pada saat itu juga semua pelaku Sapu sudah resmi menjadi orang yang dewasa, sebagai anak adat dan telah berwibawa menurut perspektif adat masyarakat Lo'a. Pelaku Sapu yang sudah berpakaian adat kembali ke kampung dan harus melakukan aktivitas mengundang semua warga kampung [3].

Keterlibatan warga suku menjadi bagian yang sangat penting dalam kehidupan sosial masyarakat Lo'a. Jika warga yang tidak melibatkan diri dalam kegiatan upacara ini akan menjadi bahan pembicaraan dalam kampung dan berdampak pada sikap apatis warga suku terhadap yang bersangkutan. Dalam bahasa setempat julukan untuk yang tidak terlibat dikenal dengan ungkapan Bu'e Woe, No'o Hoga Woe Bha'i artinya yang bersangkutan tidak mempunyai teman baik aro dhea ulu eko. Makanan yang dihidangkan dalam upacara $\mathrm{Ka}$ Sona perempuan maupun laki-laki [3].

c. Penutup

Tahap terakhir dari rangkaian ritual adat Sapu adalah Teza moe. Teza moe adalah pemberian daging oleh pihak Mori Gae kepada Ana Weta dengan tujuan mengingatkan Ana Weta bahwa si Mori Ga'e masih ada, dan suatu saat nanti Anaweta yang mendapatkan daging tersebut harus memberikan balasan berupa ayam atau telur ayam kepada Mori Ga'e. Hal ini tidak dilakukan kepada sembarangan orang. Yang biasa melakukan Teza Moe harus mengikuti garis keturunan bapak baik yang dekat maupun keturunan yang jauh [3].

Dengan berakhirnya Teza moe maka seluruh rangkaian kegiatan Sapu-pun dinyatakan selesai. Makanan yang telah dibagikan harus dibawa pulang ataupun dimakan pada tempat itu juga. Di sinilah akan nampak sebuah ikatan kekeluargaan yang telah terjalin itu mulai diuraikan kembali sehingga keturunan-keturunan yang mungkin sebelum pelaksanaan ritual terlupakan akan diperhitungkan kembali. Suasana persatuan nampak pada upacara penutup ini. Di tempat makan bersama itulah nanti akan memunculkan banyak gagasan atau ide yang pada intinya adalah untuk memajukan keluarga besar mereka masing-masing di kemudian hari [3].

Berbagai aktivitas manusia pada masa lampau selalu meninggalkan jejak sama halnya dengan aktivitas budaya suatu masyarakat yang diwariskan kepada generasi berikutnya. Kebudayaan tidak dapat dilakukan secara terpisah dengan masyarakat pendukungnya, hal ini sangat jelas karena kebudayaan selalu berhubungan dengan masyarakat yang terdiri dari sekumpulan orang atau manusia. Manusia dalam kehidupan sehari-harinya memerlukan kerjasama antar sesama baik untuk mengembangkan keturunan maupun untuk melangsungkan kehidupannya. Untuk membina ketertiban kehidupan dalam hidup bermasyarakat perlu suatu pengendalian agar tercipta keharmonisan hidup [3].

Dalam upacara adat Sapu juga diberlakukan berbagi simbol-simbol. Simbol-simbol dan struktur-struktur upacara dengan demikian berfungsi sebagai jembatan untuk mengantarai satuan-satuan kenyataan- 
kenyataan yang ada dan berbeda-beda dari pengalaman manusia. Hal ini dapat mungkin terjadi karena kedudukan manusia sebagai makhluk hewan yang tertinggi tingkatan kedudukannya dan karena keuniversalan dari motif-motif dan dasardasar kognitif yang dipunyai oleh manusia. Sehubungan dengan simbol, Turner (1982:19) menyatakan bahwa "The symbol is the smal $\neg$ lest unit of ritual which still retains the specific properties of ritual behavior. It is the ultimate unit of specific structure in a ritual con $\neg$ text". Maksudnya, simbol adalah unit (bagian) terkecil dalam ritual yang mengandung makna dari tingkah laku ritual yang bersifat khusus. Simbol tersebut merupakan unit pokok dari struktur khusus dalam konteks ritual.

\section{METODOLOGI PENELITIAN}

Untuk memperoleh data yang dapat menunjang website ini, diperlukan data teoritis dan data lapangan, untuk menghasilkan data dan informasi yang berhubungan dengan pembuatan website ini.

\section{Studi kepustakaan}

Dilakukan dengan mencari literatur pendukung penelitian yang berhubungan dengan pembuatan website perencanaan anggaran ritual ada sapu. Pengumpulan data juga diakukan dengan pencarian data dari buku, browsing internet atau literatur-literatur lain yang berkaitan dengan teori dasar dari sistem yang sedang dikembangkan, dan dokumen yang berkaitan dengan data yang diperlukan untuk penelitian maupun perancangan sistem.

\section{Metode observasi}

Observasi dilakukan dengan cara mengadakan pengamatan langsung terhadap suatu objek yang akan diteliti yaitu lokasi tempat perencanaa ritual ada sapu.

3. Metode pengembangan perangkat lunak

Berikut ini adalah metode-metode yang digunakan untuk membangun website analisis anggaran ritual adat sapu.

a. Analisis kebutuhan perangkat lunak: dilakukan untuk mengdapatkan kebutuhan perangkat lunak yang akan dibangun.

b. Perancangan perangkat lunak: dilakukan untuk merancang perangkat lunak yang akan dikembangkan sehingga dapat diperoleh gambaran detail sistem.

c. Implementasi perangkat lunak (coding): dilakukan dengan mengembangkan website analisis anggaran ritual adat sapu.

4. Pengujian perangkat lunak
Pengujian perangkat lunak dilakukan dengan pengujian fungsionalitas perangkat lunak yang dilakukan oleh pengembangan perangkat lunak dan juga pengujian tampilan dan unjuk kerja sistem yang dilakukan oleh pengguna perangkat lunak (masyarakat atau pihak penyelenggara ritual adat sapu).

\section{ANALISIS DAN PERANCANGAN SISTEM}

1. Arsitektur perangkat lunak

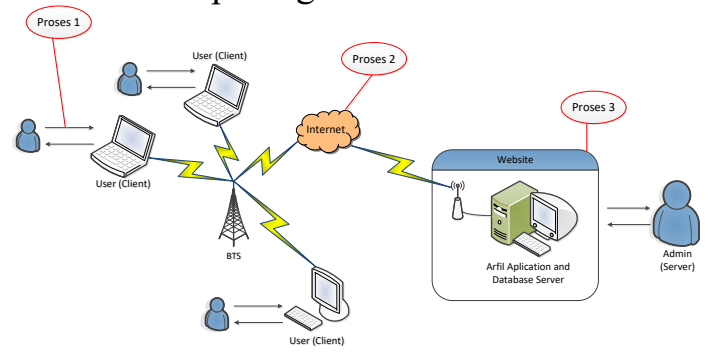

Gambar 1. Arsitektur perangkat lunak

Komponen-komponen yang terlibat di dalamnya yaitu:

a. Penyedia layanan website, yang mana di dalamnya terdapat server aplikasi dan server database. website akan diterapkan atau dikelolah oleh admin.

b. Peralatan input dan output yang akan digunakan oleh pengguna untuk melakukan pengolahan data dalam website.

c. Peralatan jaringan komputer yang akan digunakan untuk menghubungkan komputer dengan internet.

Berikut ini akan dijelaskan proses-proses yang terjadi pada tahap implementasi website, seperti yang ditunjukan pada gambar 8 di atas.

a. Proses pertama terjadi pada pengguna

Pengguna Website dapat dibedakan menjadi dua jenis yaitu user dan admin. Admin berfungsi untuk melakukan pengolahan data admin dan data master. Sedangkan user hanya dapat melakukan proses pencarian dan displaydata. Setiap permintaan pengolahan data oleh pengguna akan dikirim dan dikelola lebih lanjut oleh website dan database server selanjutnya akan dikembalikan kepada pengguna berupa informasi-informasi yang ditampilkan pada layar monitor maupun informasi-informasi yang dapat dicetak.

b. Proses kedua terjadi pada jaringan internet

Jaringan internet merupakan komponen penting dalam sistem Website. Pada tahap ini, jaringan internet bertindak sebagai penghubung antara pengguna (client) dan server. Permintaan pengolahan data oleh pengguna akan ditransmisikan melalui jaringan 
internet. Dengan demikian website dapat diakses oleh siapa saja, kapan dan di mana saja berada selama koneksi jaringan internet tidak bermasalah.

c. Proses ketiga terjadi pada komputer server

Pada tahap ini, komputer server yang terinstal website dan database server bertanggungjawab untuk menerima permintaan pengolahan data yang dikirim oleh pengguna melalui perantaraan media internet. Permintaan pengolahan data tersebut selanjutnya akan diproses dan hasilnya akan dikirimkan kembali kepada masing-masing pengguna sesuai dengan permintaan.

\section{ERD}

adalah Entity Relationship Diagram (ERD) mendeskripsikan perancangan basis data pada peringkat logika. ERD merupakan suatu model untuk menjelaskan hubungan antar data dalam basis data berdasarkan objek-objek dasar data yang mempunyai hubungan antar relasi. ERD untuk memodelkan struktur data dan hubungan antar data, untuk menggambarkannya digunakan beberapa notasi dan simbol.

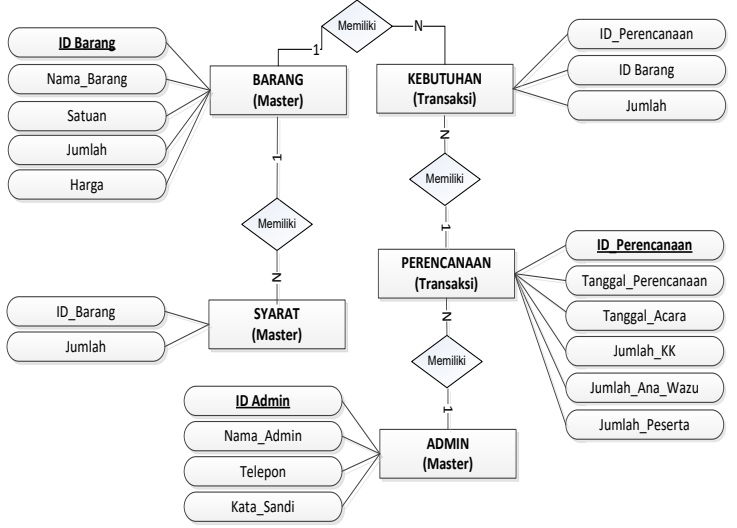

Gambar 2. ERD

\section{Alur dokumen}

Diagram alur dokumen merupakan bagan yang menunjukkan arus pekerjaan secara keseluruhan dari suatu sistem secara logika. Bagan ini menunjukkan urut-urutan dari prosedur-prosedur yang ada di dalam program dan berfungsi sebagai alat bantu komunikasi dan dokumentasi. Di dalam penyusunan dokumentasi, aturan atau aliran data, prosedur biasa-nya digambarkan dengan simbol dan menggunakan "Flowcharing Symbol" yang disahkan oleh USA Standard Institute.

Bagan alur dokumen juga dapat diartikan sebagai alat penentu arus pekerjaan secara keseluruhan dari sistem. Alur sistem pada proses pembuatan program ini dapat dilihat pada gambar berikut.

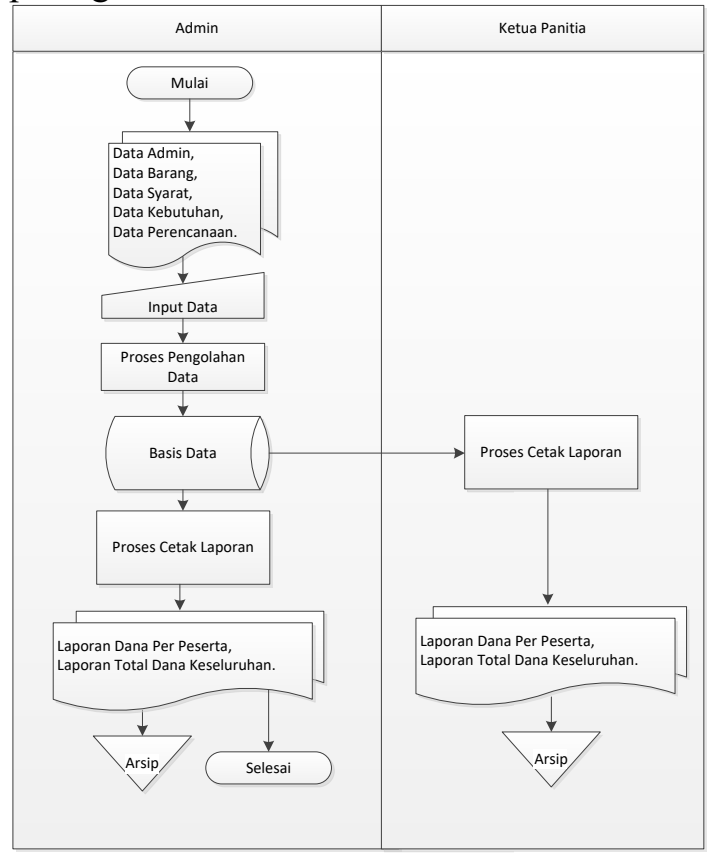

Gambar 3. Alur dokumen

4. Diagram konteks

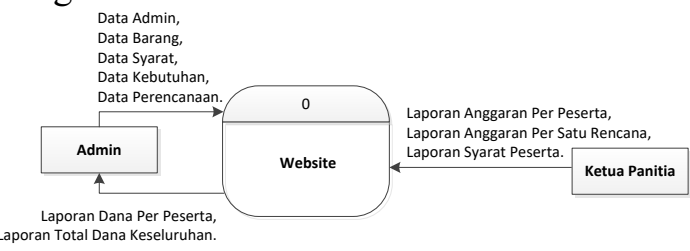

Gambar 4. Diagram konteks

Diagram konteks adalah sebuah diagram sederhana yang menggambarkan hubungan satu dengan yang lain dengan aliran dan penyimpanan data atau sebuah diagram yang menggambarkan hubungan input atau output antara sistem dengan dunia luar (kesatuan luar). Diagram konteks dapat dilihat pada gambar 4 di atas.

\section{HIPO}

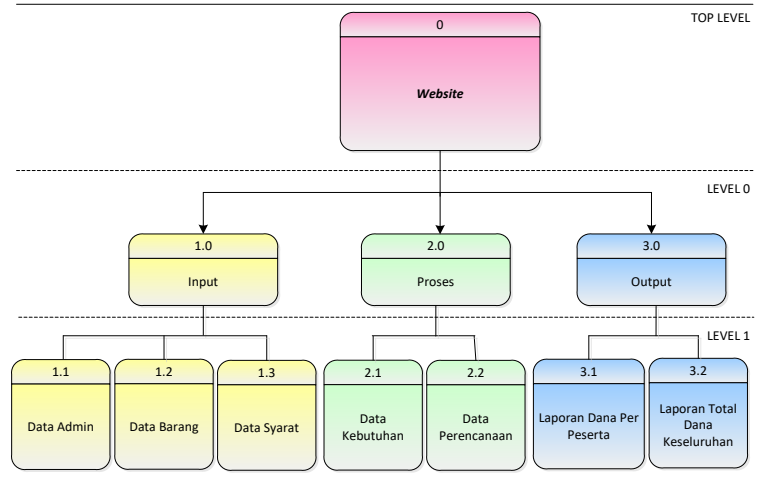

Gambar 5. HIPO 


\section{DFD}

Data flow diagram adalah suatu model untuk menggambarkan aliran data dan proses dalam mengolah data pada suatu sistem.

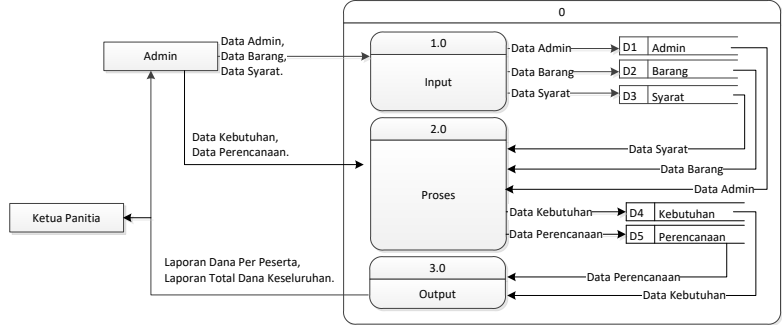

Gambar 6. DFD

\section{HASIL DAN PEMBAHASAN}

E-sapu adalah sebuah perangkat lunak yang dibangun untuk membantu admin, menghitung jumlah anggaran yang dibutuhkan untuk menyelenggarakan ritual adat sapu. ESapu dibuat dengan menggunakan bahasa pemrograman php. Sedangkan untuk mengelolah database management sistem (DBMS) digunakakan MySQL.

\section{Antarmuka login dan menu utama}

Login merupakan fasilitas tambahan dalam Apram yang berfungsi sebagai autentikasi atau untuk memastikan pengguna Apram adalah benar- benar pengguna yang sah. Jika proses login berhasil setelah pengguna memasukan username dan password maka website akan menampilkan daftar menu pilihan yaitu master, transaksi dan cetak laporan. Tampilannya dapat dilihat pada gambar 7 berikut ini

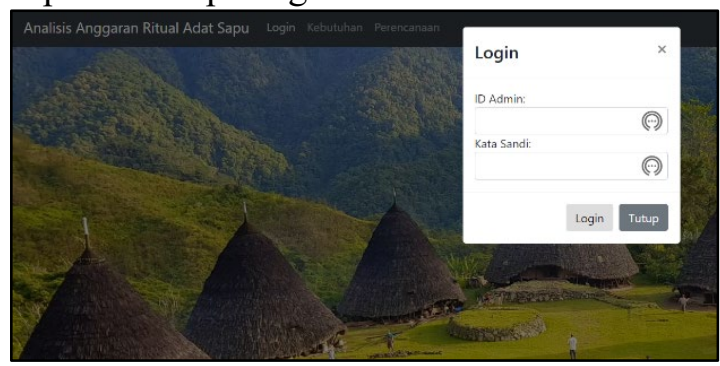

Gambar 7. Antarmuka login dan menu utama

\section{Antarmuka pengolahan data kebutuhan}

Antarmuka pengolahan data kebutuhan merupakan antarmuka master yang digunakan untuk mengolah data kebutuhan seperti menambah, menghapus dan mengubah data kebutuhan. Id kebutuhan akan diciptakan secara otomatis oleh sistem saat ada penambahan data kebutuhan baru. Antarmuka pengolahan data kebutuhan dapat dilihat pada gambar 8 berikut ini.

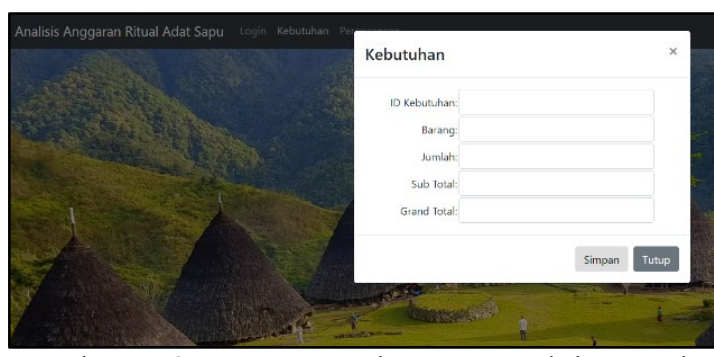

Gambar 8. Antarmuka pengolahan data kebutuhan

3. Antarmuka pengolahan data perencanaan Antarmuka pengolahan data perencanaan merupakan antarmuka master yang digunakan untuk mengolah data perencanaan seperti menambah, menghapus dan mengubah data perencanaan. Id perencanaan akan diciptakan secara otomatis oleh sistem saat ada penambahan data perencanaan baru. Antarmuka pengolahan data perencanaan dapat dilihat pada gambar 9 berikut ini.

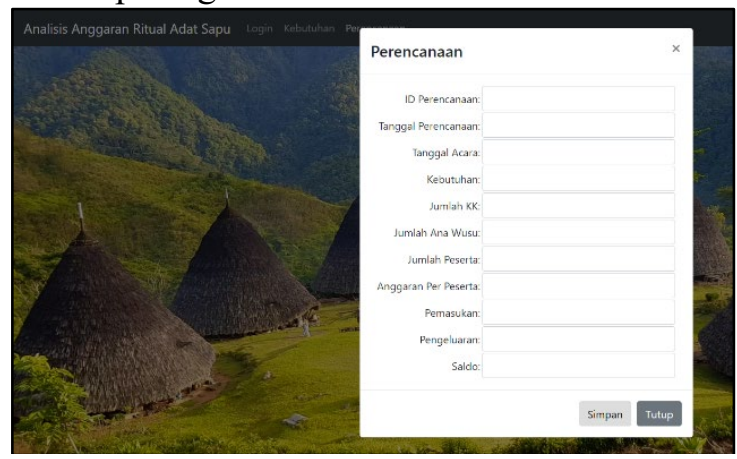

Gambar 9. Antarmuka pengolahan data perencanaan

\section{PENGUJIAN PENGGUNA}

Pengujian unjuk kerja sistem dilakukan dengan melakukan pengujian kepada pengguna sistem yang dikembangkan. Dalam pengujian unjuk kerja sistem ini diambil 10 responden dari kalangan masyarakat Kabupaten Ngada. Hasil rekapan kuesioner dapat dilihat pada tabel 1 berikut ini.

Tabel 1. Rekapan kuesioner pengguna

\begin{tabular}{|l|l|l|l|l|l|}
\hline $\begin{array}{l}\text { N } \\
\text { o }\end{array}$ & Pernyataan & 4 & 3 & 2 & 1 \\
\hline 1 & $\begin{array}{l}\text { Pemilihanwarn } \\
\text { abaner dan } \\
\text { antarmuka } \\
\text { pada } \\
\text { setiaphalaman } \\
\text { websitesudahs } \\
\text { esuaidan dan } \\
\text { nyamandilihat } \\
\text { (user friendly) }\end{array}$ & 7 & 3 & 0 & 0 \\
\hline
\end{tabular}




\begin{tabular}{|l|l|l|l|l|l|}
\hline & $\begin{array}{l}\text { Website dapat } \\
\text { membantu } \\
\text { admin untuk } \\
\text { melakukan } \\
\text { analisis } \\
\text { rencana ina } \\
\text { anggaran ritual } \\
\text { adat sapu } \\
\text { secara cepat, } \\
\text { tepat dan } \\
\text { akurat }\end{array}$ & 8 & 2 & 0 & 0 \\
\hline 3 & $\begin{array}{l}\text { Memudahkan } \\
\text { proses } \\
\text { perekapan dan } \\
\text { pencetakan } \\
\text { laporan dana } \\
\text { per peserta dan } \\
\text { total dana } \\
\text { secara } \\
\text { keseluruhan }\end{array}$ & 0 & 0 & 0 \\
\hline 4 & $\begin{array}{l}\text { Informasi yang } \\
\text { disajikan oleh } \\
\text { Website jelas } \\
\text { dan terperinci }\end{array}$ & 9 & 1 & 0 & 0 \\
\hline $\begin{array}{l}\text { Meminimalkan } \\
\text { kesalahan yang } \\
\text { diakibatkan } \\
\text { oleh human } \\
\text { error }\end{array}$ & 7 & 3 & 0 & 0 \\
\hline
\end{tabular}

Keterangan:

4: Sangat setuju

3: Setuju

2: Kurang setuju

1: Tidak setuju

Pemilihan warna baner dan antarmuka pada setiap halaman website sudah sesuai dan nyaman dilihat (user friendly). Mayoritas responden menjawab sangat setuju dengan detail penilaian: 7 jawaban sangat setuju, 3 jawaban setuju, 0 jawaban kurang setuju dan 0 jawaban tidak setuju.

Website dapat membantu admin untuk melakukan analisis rencana anggaran ritual adat sapu secara cepat, tepat dan akurat. Mayoritas responden menjawab sangat setuju dengan detail penilaian: 8 jawaban sangat setuju, 2 jawaban setuju, 0 jawaban kurang setuju dan 0 jawaban tidak setuju.

Memudahkan proses perekapan dan pencetakan laporan dana per peserta dan total dana secara keseluruhan. Semua responden menjawab sangat setuju.

Informasi yang disajikan oleh website jelas dan terperinci. Mayoritas responden menjawab sangat setuju dengan detail penilaian: 9 jawaban sangat setuju, 1 jawaban setuju, 0 jawaban kurang setuju dan 0 jawaban tidak setuju.

Meminimalkan kesalahan yang diakibatkan oleh human error. Mayoritas responden menjawab sangat setuju dengan detail penilaian: 7 jawaban sangat setuju, 3 jawaban setuju, 0 jawaban kurang setuju dan 0 jawaban tidak setuju.

Grafik hasil pengujian pengguna dapat dilihat pada gambar 10 berikut ini.

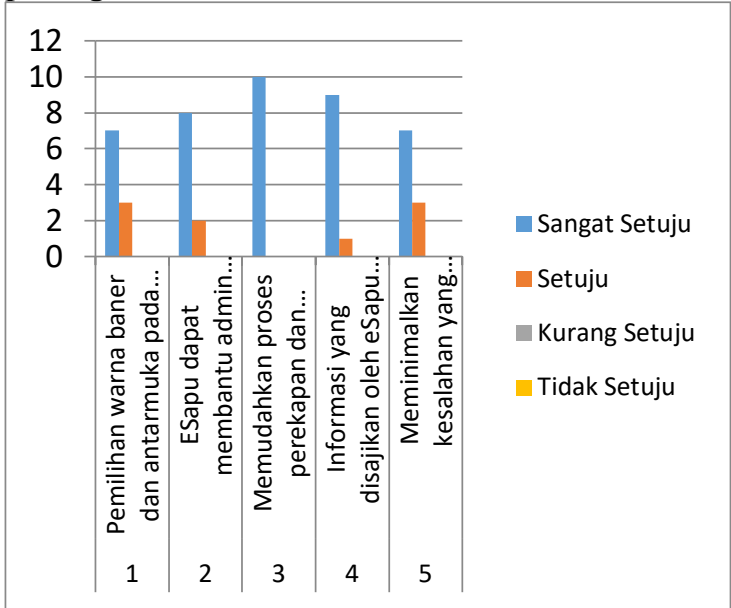

Gambar 10. Grafik hasil pengujian pengguna

Berdasarkan hasil uji responden dapat disimpulkan bahwa secara umum sistem ini sudah memenuhi tujuan utamanya yaitu dapat untuk membantu admin, menghitung jumlah anggaran yang dibutuhkan untuk menyelenggarakan ritual adat sapu. Memudahkan proses perekapan dan pencetakan laporan dana per peserta dan total dana secara keseluruhan. Dari segi tampilan sudah baik, interaktif dan user friendly, mudah dibaca dan dipahami serta pemilihan warna yang nyaman dan indah untuk dipandang.

\section{Kelebihan dan Kekurangan}

Setelah dilakukan pengujian fungsionalitas perangkat lunak, dan pengujian unjuk kerja sistem, ditemukan beberapa kelebihan dan kekurangan dari sistem, diantaranya adalah sebagai berikut:

1. Kelebihan: sistem dapat menangani proses pengolahan data master dan transaksi dengan cepat, tepat dan akurat.

2. Kekurangan: website ini tidak memiliki fungsi help atau petunjuk pemakaian sehingga akan membutuhkan waktu lama dalam proses pembelajaran telebih lagi jika pengguna benar-benar awam akan teknologi informasi. 


\section{SIMPULAN}

Pada penelitian ini telah dibangun sebuah perangkat lunak (bernama eSapu) yang dapat membantu admin, menghitung jumlah anggaran yang dibutuhkan untuk menyelenggarakan ritual adat sapu. Memudahkan proses perekapan dan pencetakan laporan dana per peserta dan total dana secara keseluruhan. Dari segi tampilan sudah baik, interaktif dan user friendly, mudah dibaca dan dipahami serta pemilihan warna yang nyaman dan indah untuk dipandang. ESapu dibuat menggunakan bahasa pemrograman php Untuk mengelolah database management system (DBMS) digunakakan MySQL.

\section{DAFTAR PUSTAKA}

[1] Bere, D., 2013, Aplikasi Perencanaan Anggaran Pesta Pernikahan, Skripsi, STIKOM Uyelindo, Kupang

[2] Djauhari, V.M., 2009, Analisis Anggaran Biaya Operasional pada PT. Pelabuhan Indonesia I, Draft Skripsi, Universitas Sumatera Utara, Medan

[3] Erlin, 2012, Ritual Adat Sapu di Desa Lo'a kecamatan So'a Kabupaten Ngada, Skripsi, Universitas Flores, Ende

[4] Megawati, 2012, Proses Penyusunan Realisasi Anggaran Penerimaan dan Pengeluaran Kas pada Rumah Sakit Umum Daerah Salatiga, Universitas Kristen Satya Wacana, Salatiga

[5] Nurtanto, T.D., Adnan, M., 2011, Aplikasi Pendataan Kependudukan, Pendapatan dan Pengeluaran Desa di Desa Kalidengen, Naskah Publikasi, STMIK AMIKOM, Yogyakarta 